\title{
Material Research of a Decorative Bronze Circle from the Hallstatt Culture Period
}

\section{Šárka Msallamová, Jiř́ Kmošek, Alena Michalcová}

Institute of Chemical Technology Prague, Department of Metals and Corrosion Engineering, Technická 5, 16628 Prague 6,msallams@vscht.cz; jirkakomsek@seznam.cz; michalca@vscht.cz

The paper deals with material research of a bronze circle from the Hallstatt culture period. The structure of bronze was observed with an optical microscope and scanning electron microscope. The structure corresponds to wrought tin bronze after recrystallization annealing. One original repair of the crack in the material which was done by cast bronze, was determined. The bronze contains a big amount of sulphide inclusions, which are oriented in a direction of forming material. Chemical composition of the alloy and non-ferrous inclusions were determined by the EDS analyser and minority elements were determinated by the XRF spectrometer. The bronze contains 9 to 10 wt. \% Sn with minority elements $\mathrm{Pb}$, Ni and Fe. XRD and SEM were used in order to identify nonequilibrum $\mathrm{Cu}-\mathrm{Sn}$ phases. The results were compared with EBSD analysis. The nonequilibrium phase $\mathrm{Cu}_{39} \mathrm{Sn}_{11}$ was reliably determined by EBSD analyser.

Keywords: archaeological bronze, nonequilibrium phase, SEM-EDS, EBSD, XRD

\section{Acknowledgement}

Research is financially supported by the Czech Science Foundation (project no. P108/12/G043).

\section{References}

[1] CHYTRÁČEK, M., DRDA, P., KOUTECKÝ, D., MICHÁLEK J., VENCLOVÁ, N., VOKOLEK, V. (2008). Archeologie pravékých Čech 6, pp. 102-103. AV, Prague.

[2] CHVOJKA, O., MICHÁLEK, J. (2011). Výzkumy Josefa Ladislava Píče na mohylových pohřebištích doby bronzové a halštatské v jižních Čechách, pp. 83-84. National Muzeum, Prague.

[3] TYLECOTE, R. F. (1992). A History of Metallurgy, pp. 47-62. The Institute of materials, Great Britain.

[4] OTTAWAY, B. S. (1994). Prähistorische Archäometallurgie, Leidorf, Germany.

[5] SCOTT, D. A. (1991). Metallography and Mictrostructure of Ancient and Historic Metals, pp. 2-9. The Getty Conservation Institute, Singapore.

[6] WANG, Q., OTTAWAY, B. S. (2004). Casting Experiments and Microstructure of Archaeologically Relevant Bronzes, Archaeopress, Great Britain.

[7] SCHVARTZ, A.J., KUMAR, M., ADAMS, B.L., FIELD D.P. (2009). Electron Backscatter Diffraction in Material Science, pp. 65-77. Springer, USA.

[8] NOVAK-MARCINCIN, J., TOROK J., BARNA J., NOVAKOVA-MARCINCINOVA, L. (2012). Technology of Perspective Scanning Methods for Realization of 3D Models of Manufacturing Devices. In: Manufacturing Technology, Vol. 12, No. 13, pp. 186-191.

[9] NOVÁK, P., MICHALCOVÁ A., MAREK I., VODĚROVÁ M., VOJTĚCH D. (2012). Possibilities of the observation of chemical reactions during the preparation of intermetallics by reactive sintering. In: Manufacturing Technology, Vol. 12, No. 13, pp. 197-201. 